\title{
Workers with elderly dependants: employment law's response to the latest care-giving conundrum
}

Article

Accepted Version

James, G. and Spruce, E. (2015) Workers with elderly dependants: employment law's response to the latest caregiving conundrum. Legal Studies: The Journal of the Society of Legal Scholars, 35 (3). pp. 463-479. ISSN 1748-121X doi: https://doi.org/10.1111/lest.12073 Available at https://centaur.reading.ac.uk/37744/

It is advisable to refer to the publisher's version if you intend to cite from the work. See Guidance on citing.

To link to this article DOI: http://dx.doi.org/10.1111/lest.12073

Publisher: Wiley-Blackwell

All outputs in CentAUR are protected by Intellectual Property Rights law, including copyright law. Copyright and IPR is retained by the creators or other copyright holders. Terms and conditions for use of this material are defined in the End User Agreement.

www.reading.ac.uk/centaur 
Central Archive at the University of Reading

Reading's research outputs online 


\section{Workers with Elderly Dependants: Employment Law's Response to the Latest Care- giving Conundrum}

\section{Grace James and Emma Spruce*}

University of Reading

This paper considers how employment laws are being used in response to what we have termed 'the eldercare/workplace conundrum'. It is well known that people are now living longer but health is still failing in a significant percentage of older people, meaning that many adults require care for longer, albeit to varying degrees and for varying amounts of time. Many of these individuals will receive care from relatives or close friends who are participating in the labour market: this is increasingly likely as adults are expected / wanting to remain in paid work for longer, often into their $60 \mathrm{~s}$ and $70 \mathrm{~s}$. The requirements of elderly dependants can cause these workers huge difficulties and dilemmas as they attempt, across time, to accommodate the particular needs of the person for whom they wish to provide care, often a loved one, and meet the particular demands of their employment relationship. In this paper we consider why this is an area of social policy that warrants effective legal engagement and consider, drawing on various examples of legal responses in other countries that face similar conundrums, what might improve legal engagement in this area.

\section{INTRODUCTION}

\footnotetext{
* Emma Spruce co-authored as part of an Undergraduate Research Opportunity Programme (UROP) funded by the University of Reading. We thank Eugenia Caracciolo di Torella, Rachel Horton and the anonymous reviewers for their useful comments.
} 
Life expectancy has increased in the past 60 years or so and we now live longer, often into our 70s, and increasingly into our $80 \mathrm{~s}$ and $90 \mathrm{~s}^{1}$. This demographic shift is being experienced, albeit at different rates and with different consequences for individuals, families and states, across the globe ${ }^{2}$. We may be living longer, and this is indeed 'wonderful news', ${ }^{3}$, but health is still failing in a significant percentage of our older generation: the looming dementia crisis provides an illustrative example, with predictions that cases worldwide will double every 20 years - to an estimated 66 million by 2030 and 115 million by $2050^{4}$. This 'longevity revolution, ${ }^{5}$ has consequences that we ignore at our peril. Increasing life expectancy, when coupled with failing health, means that a significant number of adults will need to receive care, in varying ways and to varying degrees and for varying amounts of time, from another individual and/or institution. In an era of dwindling community care initiatives and an agenda that favours home care for the elderly this role, or a major proportion of it, is increasingly undertaken by family members and/or close friends. In fact, Carers UK estimates that over 6.5 million people currently provide care for adults who are ill, frail or disabled and predict that this figure will rise by $40 \%$ (or 2.6 million) by 2037 - meaning that this cohort of carers is likely to reach 9 million in the $\mathrm{UK}^{6}$; figures that are echoed in other countries ${ }^{7}$. As the

\footnotetext{
${ }^{1}$ ONS Statistical Bulletin: Historical and Projected Mortality Data from Period and Cohort Life Tables, 2012 based, UK, 1981-2062 (2013) available at http://www.ons.gov.uk/ons/dcp171778_345078.pdf (last checked 02/09/14). See also, Age Concern Older People in the UK, (UK: Age Concern, 2008).

${ }^{2}$ See http://www.who.int/gho/countries/en/ (last checked 02/09/14). According to one survey, the UK's population is ageing more slowly than other comparable countries (see ONS Population Trends 42, (London: ONS, December 2010) cited in Age UK Later Life in the United Kingdom (London: Age UK, 2013) p3. For a discussion see P Lloyd-Sherlock (ed) Living Longer: Ageing, Development and Social Protection (London: Zed Books, 2004).

${ }^{3}$ J Herring Older People in Law and Society (Oxford: Oxford University Press, 2009) p1.

${ }^{4}$ Alzheimer's Disease International The Global Impact of Dementia 2013-2050, (London: ADI, 2013) available at http://www.alz.co.uk/research/GlobalImpactDementia2013.pdf (last checked 08/01/14).

${ }^{5} \mathrm{R}$ Butler The Longevity Revolution: The Benefits and Challenges of Living a Long Life (New York: Public Affairs, 2008).

${ }^{6}$ Carers UK Facts about Carers 2012 (London: Carers UK, 2012), available at http://www.carersuk.org/media/k2/attachments/Facts_about_carers_Dec_2012.pdf (last checked 08/01/14). See also L Pickard 'A Growing Care Gap? The Supply of Unpaid Care for Older people by their Adult Children in England to 2032' (2013) Ageing and Society p1-18 (online ISSN 0144-686X) in press, cited in C McNeil, and J Hunter The Generation Strain: Collective Solutions to Care in An Ageing Society (London: Institute for Public Policy Research, 2014) p7.

${ }^{7}$ See for example, MetLife Mature Market Institute The MetLife Study of Caregiving Costs to Working Caregivers: Double Jeopardy for baby Boomers Caring for Their Parents (US: MetLife, 2011) available at
} 
Canadian Caregiving Coalition put it, 'it is not a matter of if you become a caregiver, but when ${ }^{, 8}$. Crucially for our focus, many such carers are also involved in paid work - around one in eight workers in the UK (three million people) currently combine work with caring for a disabled, ill or frail relative or friend - with over two million working full time and one million part-time ${ }^{9}$ - a figure that, given the demographic shift and the fact that more people are expected to / want to participate in paid work into their $60 \mathrm{~s}$ and $70 \mathrm{~s}$, is only going to increase $^{10}$. In addition, research suggests that the demand for informal care means that those who provide it will be required to do so for an increased number of hours and for a longer duration $^{11}$, often portrayed in popular press and academic literature as a 'ticking time-bomb', a 'perfect storm'12 or a 'generation strain'13. Whilst reluctant to perpetuate these negative constructions of ageing, there is no doubting that, given the need to facilitate and extend the workplace participation of older workers coupled with greater reliance on home and familybased care, work-eldercare conflicts are a reality for a growing number of workers. In addition, the commercialisation of care work means that, even where the worker is not personally undertaking care-work, or all of it, personal budgets are often drawn upon to provide care (by others) and the financial implications of this need to be factored into the equation.

https://www.metlife.com/mmi/research/caregiving-cost-working-caregivers.html\#key\%20findings (last checked 02/09/14), which estimates that there are over 9.7 million parental carers over the age of 50 in the US: a conservative assessment given that this figure does not include younger carers or those caring for other elderly dependants.

${ }^{8}$ Canadian Caregiver Coalition Respite: A Challenge for Caregivers, Service Providers and Policy Makers (2001) p5, cited in L Duxbury, C Higgins and R Smart Elder care and the impact of caregiver strain on the health of employed caregivers (Ontario Canada: IOS Press, 2010) 30.

${ }^{9}$ Carers UK above $\mathrm{n} 6$.

${ }^{10}$ See also, A Borgsch-Supan, K Hank and H Jurges 'A New Comprehensive and International View on Ageing: Introducing the "Survey of Health, Ageing and Retirement in Eurpoe"' (2008) in PA Kemp, K Van den Bosch and L Smith (eds) Social Protection in an Ageing World (Antwerp: Intersentia, 2008).

${ }^{11}$ See discussion in C McNeil and J Hunter The Generation Strain: Collective Solutions to Care in An Ageing Society (London: Institute for Public Policy Research, 2014) p10.

${ }^{12}$ B Schroeder, J Macdonald and J Shamian 'Older Workers with Caregiving Responsibilities: A Canadian Perspective on Corporate Caring' in J Barratt Keeping Older Workers in the Labour Force and Caring for a Family Member: Can We Be in two Places At Once? (Toronto: International Federation on Ageing, 2011) p29.

${ }^{13}$ Above n 11. 
For those in paid employment, caring for elderly dependants can have a huge impact upon their immediate and long term working relationships and identities. Caring for as little as ten hours a week can, according to recent research, have a detrimental impact upon employment participation $^{14}$. Unlike childcare requirements, eldercare responsibilities can arrive unexpectedly and have an unpredictable trajectory as the nature of care needed can fluctuate and the duration of need is often unknown. This causes these workers unprecedented, for them at least, difficulties and dilemmas as they attempt to accommodate the particular needs of the person for whom they wish to provide care and meet the particular demands of their employment: what we term, 'eldercare/workplace conundrums'. These conundrums are not dealt with in isolation but manifest themselves as a journey: one which involves all manner of decisions (major and minor, immediate and long term) with various people - such as the recipients of care, other relatives, social services, medical professionals, solicitors - within a host of very diverse contexts which can vary according to, for example, the nature of the 'dependency' or care needs, the physical location of carer/recipient of care and strength of wider support network. In sum, when responsibility for the care needs of adult dependants become relevant to workers lives, these individuals are (a) renegotiating the boundaries of their private relationships as 'the notion of fixed, bounded demarcation of responsibility changes ${ }^{15}$ (e.g. from spouse, partner or parent to 'dependant relative') and simultaneously (b) re-negotiating their worker identity in light of their new circumstances.

The realities of an ageing population challenges a host of legal frameworks and social policies - testing, for example, our community care policies, health care, pension provisions

\footnotetext{
${ }^{14}$ See D King and L Pickard 'When is Carer's Employment At Risk? Longitudinal Analysis of Unpaid Care and Employment in Midlife' (2013) 21(3) England Health and Social Care in the Community 303.

${ }^{15} \mathrm{D}$ Weakes, H Wilkinson and S Davidson 'Families, relationships and the impact of dementia - insights into the 'ties that bind"' in L Mckie and S Cunningham-Burley (eds) Families in Society: Boundaries and Relationships (Bristol: Policy Press, 2005) p149.
} 
and retirement laws ${ }^{16}$. In this article we consider how the regulation of workers with elderly dependants might be improved within employment law frameworks and suggest how focus upon three core issues (finance, coverage and flexibility) are key. Before doing so we consider, in section 2, why governments and employers should engage with this latest caregiving conundrum?

\section{WHY ENGAGE WITH ELDERCARE-WORKPLACE CONUNDRUMS?}

Historically, governments have perceived all care-giving / workplace conundrums as 'a private responsibility to be negotiated between individual employers and workers ${ }^{17}$ and have been reluctant to regulate this aspect of worker/ employer relationships. Today, the needs of working parents of young children have moved up the political agenda and are now being tackled in many countries, but the needs of workers with eldercare responsibilities remain very low down the priority list. This article seeks to challenge current legal responses ${ }^{18}$ and there are three, inter-related, strands to our justification for better legal engagement.

The first strand of our motivation for encouraging governments to do more in this field of social policy is our belief that effective legal recognition of working care-givers is crucial for the promotion of gender equality in the labour market. The fact that mothers bear the brunt of child care-giving responsibilities has been well documented and critiqued ${ }^{19}$. Women, the

\footnotetext{
${ }^{16}$ See J Herring above $\mathrm{n}$ 3. Indeed, it has been suggested that focus on four 'pillars' - family, community, market and state - are important to bring about lasting social change in this area: see C McNeil and J Hunter above $\mathrm{n} 11, \mathrm{p} 7$.

${ }^{17} \mathrm{~N}$ Busby and G James (eds) Families, Caregiving and Paid Work; Challenging Labour Law in the $21^{\text {st }}$ Century (Cheltenham: Edward Elgar, 2011) p2.

${ }^{18}$ For an overview see J Herring Carers and the Law (Oxford: Hart Publishing, 2013).

${ }^{19}$ See, for example, R Crompton Employment and the Family: The Reconfiguration of Work and Family Life in Contemporary Societies (Cambridge: Cambridge University Press, 2006); M Fineman The Autonomy Myth: A
} 
world over, are often constructed as 'predominantly and inevitably responsible for home and childrearing responsibilities, providing consistent and selfless nurturing which, where necessary, forsakes self-fulfilment and independence... ${ }^{, 20}$ and eldercare is often constructed as a natural extension of this norm. It is therefore no surprise that elder-care-giving tasks are, despite the growing acceptance of men's capacity as carers, still predominantly undertaken by women ${ }^{21}$ who care for longer hours and for a longer duration than men ${ }^{22}$ and are more likely to give up work as a result ${ }^{23}$. In addition, women are more likely to be dual-carers ${ }^{24}$ - a growing cohort of workers, known colloquially as the 'sandwich generation", ${ }^{25}$, who care for their children and elderly dependants. Women are also more likely to care during the 'peak age' for caring (45-64) when caring 'is likely to have the most significant impact on their careers and earning power, ${ }^{26}$.

On the whole, whilst men are providing care for elderly dependants - and those who are in work face financial and workforce disadvantage, men combine full time work and care and are more likely to be caring for a partner than an elderly parent ${ }^{27}$. Both genders struggle with eldercare/workplace conundrums, and given the demographic shifts that are forecast, men's involvement in this care-giving is likely to increase. However, we need to remain alert to the fact that, especially as women's workplace participation is already compromised by invasive

\footnotetext{
Theory of Dependency (New York: New Press, 2004); J Lewis Work-Family Balance, Gender and Policy (Cheltenham: Edward Elgar, 2009).

${ }^{20} \mathrm{G}$ James The Legal Regulation of Pregnancy and Parenting in the Labour Market (London: RoutledgeCavendish 2009) p15.

${ }^{21}$ E.g. In the UK, $58 \%$ of carers of elderly dependants are female and $42 \%$ are male (see NHS Information Centre for Health and Social Care Survey of Carers in Households 2009/10 (2010), cited in Carers UK above n6, p2.

${ }^{22}$ F Carmichael et al. 'Work-Life Imbalance: Informal Care and Paid Employment in the UK' (2008) 14 Feminist Economics 3 cited in C McNeil and J Hunter above n.11, p12.

${ }^{23}$ Carers UK It Could Be You (UK: Carers UK, 2000). See also L Pickard above n 6, p12.

${ }^{24} \mathrm{E}$ Agree, B Bissett and M Rendall 'Simultaneous Care for Parents and Care for Children Amongst Midlife British Women and Men' (2003) 112 Population Trends 29.

${ }^{25} \mathrm{Ibid}$. See also E Grundy and JC Henretta 'Between Elderly Parents and Adult Children: A New Look at the Intergenerational Care Provided by the 'Sandwich Generation' (2006) 26(5) Ageing and Society 707.

${ }^{26}$ Carers UK Carers and Family Finances Inquiry (London: Carers UK, 2013) p57.

${ }^{27}$ Ibid.
} 
inequalities, any disadvantages highlighted in this paper are likely to pose a heavier cost to female workers. As Nussbaum put it,

'.. any real society is a care-giving and care-receiving society, and must therefore discover ways of coping with these facts of human neediness and dependency that are compatible with the self-respect of the recipients and do not exploit the caregivers. This is a central issue for feminism since in every part of the world, women do a large part of this work, usually without pay, and often without recognition that it is work. ${ }^{28}$

The second of our arguments in favour of legal engagement focuses on the economic rationale for action. Such arguments, which often take centre stage in calls for legal reform in this area, primarily highlight the 'business case' on the one hand and the carer's financial needs argument on the other. The business case encapsulates the fact that, unless policy makers engage with this issue employers are likely to lose skilled employees, including corporate memory and leadership capacity and threaten future productivity, if they don't find mechanisms for enabling workers with elderly dependants to participate in labour markets and meet their care-giving responsibilities ${ }^{29}$. Many carers when faced with the 'caregiving conundrum' outlined above, reduce their working hours, take part-time jobs for which they are over-qualified or leave employment altogether in order to accommodate the needs of the recipient of their care ${ }^{30}$ - who is often a loved one - and this decision can also impact upon

\footnotetext{
${ }^{28}$ M Nussbaum 'Care, Dependency and Social Justice' in P Lloyd-Sherlock above n 2, p281.

${ }^{29}$ See, for example, J Barratt above n12.

${ }^{30}$ See for example a 1990s study in the US that found $29 \%$ of potential caregivers who decided not to choose institutional care for their parents, left the labour market or reduced their hours at work: RI Stone and PF Short 'The Competitive Demands of Employment and Informal Caregiving to Disabled Elders' (1990) 28(6) Medical Care 524, cited in T Yang and G Gimm 'Caring for Elder Parents: A Comparative Evaluation of Family Leave Laws' (2013) 41 Journal of Law, Medicine and Ethics 501 at p501. See also a UK study suggesting that more carers will stop working altogether than reduce their hours: OECD Help Wanted? Providing and Paying for Long-Term Care (OECD, 2011) cited in Carers UK above n 6, p8.
} 
their capacity to increase hours, take on a more senior role or re-enter the labour market at a later date.

The cost to economies as a whole is also worthy of consideration: the UK is estimated to have lost a staggering $£ 5.3$ billion as a result of lost earnings ( $£ 1$ billion in forgone taxes) due to people leaving the labour market to take on care-giving responsibilities for elderly or disabled dependants ${ }^{31}$. The loss of carers from the labour market also potentially creates a cycle of state dependency and increased financial vulnerability for individuals and has huge ongoing ramifications for state welfare provisions in the long term, as the carers themselves are less likely to save for their retirement and are more likely to need financial support from the state (to varying degrees) in later life. Indeed, public expenditure costs of carers who feel they can no longer work are huge - in the UK it is estimated at $£ 1.3$ billion a year ${ }^{32}$. In times of austerity reducing spending on older people's social care ${ }^{33}$ might seem appealing in the short term, but policies that fail to consider the financial ramifications of care for carers ultimately have financial consequences for state spending in the long term: it's a matter of when we pay, not if, and there are many reasons to re-consider the wisdom of current strategies of spending cuts in this context. Indeed, policy-makers and society in general appear to accept the need to finance leave provisions for childcare purposes but appear reluctant to accept that employers and/or states have a responsibility to support eldercare ${ }^{34}$.

In relation to the financial needs of carers - the potential for vulnerability is staggering: in a UK study of 4000 carers, almost half cut back on essentials like food (43\%) and heating

\footnotetext{
${ }^{31}$ L Pickard Public Expenditure Costs of Carers Leaving Employment (London: LSE Health and Social Care, 2012) cited in Age UK above n.2, p13.

${ }^{32}$ Ibid.

${ }^{33}$ See Audit Commission Social Care for Older People: Using Data from VFM Profiles, July 2013 (London: Audit Commission, 2013).

${ }^{34}$ See discussion below in section 3 .
} 
$(44 \%)$ and ended up in debt in order to make ends meet ${ }^{35}$; two in five carers who have given up paid work or reduced their working hours reported to be between $£ 10,000$ and $£ 20,000$ a year worse off ${ }^{36}$. Given that 1.6 million (14\% of) pensioners in the UK live below the poverty $\operatorname{line}^{37}$ and less than $26 \%$ of pensioner couples have less than $£ 1,500$ in savings ${ }^{38}$, this loss in earnings potential is alarming: a reality of financial vulnerability that is often tied up with other areas of law, such as property and inheritance laws, as many carers risk losing their homes, savings and inheritance to meet care costs ${ }^{39}$. If more carers were able to remain in the workplace whilst providing care to elderly dependants, and for some this will involve an injection of suitable, affordable support with the day-to-day reality of care-giving, then the economic vulnerabilities it creates for individuals and its repercussions for businesses could be alleviated.

The business case and focus on financial repercussions support the case for legal initiatives to better support workers facing this eldercare/workplace conundrum. However, we need to be cautious about framing the debate solely in these terms as it feeds what Lloyd-Sherlock has called 'the negative paradigm of population ageing and later life ${ }^{40}$ when, in fact, 'the real value of care', as Herring puts it, 'lies not in monetary terms but in the impact it has on people's lives ${ }^{41}$. Hence, the final strand of our argument for engagement focusses on the significance of care for human need: 'all societies contain people in need of care ${ }^{42}$ and we ought to challenge notions that 'those who are dependant and 'unproductive' are not full

\footnotetext{
${ }^{35}$ Carers UK State of Carers Survey, (London: Carers UK, 2013).

36 Ibid.

${ }^{37}$ Department of Work and Pensions Households Below Average Income 2010/11 (London: DWP, 2013), cited in Age UK above n 2, p16.

${ }^{38}$ Ibid.

${ }^{39}$ See above $\mathrm{n} 26, \mathrm{p} 45$.

${ }^{40}$ See P Lloyd-Sherlock 'Generalisations, Myths and Stereotypes' in P Lloyd-Sherlock above n 2, p5. Here, Lloyd-Sherlock provides evidence of this paradigm - quoting the World Bank's observation that 'the world is approaching an old age crisis... the proportion of the population that is old is expanding rapidly, swelling the potential economic burden on the young' (World Bank, 1994).

${ }^{41}$ Above n3, p97.

${ }^{42}$ M Nussbaum 'Care, Dependency and Social Justice' in P Lloyd-Sherlock above n 2, p275.
} 
participants ${ }^{43}$. In essence, we need to ensure that carers and those for whom they care are supported in a way that enables them to maintain their dignity ${ }^{44}$ and develop their full potential. Dignity and respect for elderly patients is often demanded of health care workers and recent events in the UK have underscored the government's position in this regard ${ }^{45}$. Curiously though, the wellbeing, welfare and dignity of our older generation - which includes ensuring they are adequately cared for - are often missing from debates in this area of employment law. One might argue that such consideration is outside the scope of employment relationships, yet the promotion of the welfare of children has underscored the rhetoric of UK family friendly provisions for some time ${ }^{46}$ and so there is both a precedent for considering the needs of parties outside of immediate employment relationships and doing so in a way that recognises employment law's role in responding to third party vulnerabilities and needs. Indeed, the obligation upon states to consider the needs of its elderly population is underscored in Article 25 of the EU Charter of Fundamental Rights, which has the status of primary legislation following the Treaty of Lisbon and arguably applies to all state agents, including employers, which proclaims that the Union 'recognises and respects the rights of the elderly to lead a life of dignity and independence...'.

\footnotetext{
${ }^{43}$ Ibid, p293.

${ }^{44}$ For a discussion of dignity in the context of discrimination rights - see G Moon and R Allen 'Dignity Discourse in Discrimination Law: A Better Route to Equality?' (2006) 6 European Human Rights Law Review 695.

${ }^{45}$ E.g. see Dept of Health Transforming Care: A National response to the Winterbourne View Hospital: Dept of Health Review Final Report (London: Dept of Health, 2012) available at https://www.gov.uk/government/uploads/system/uploads/attachment_data/file/213215/final-report.pdf and the Mid Staffordshire NHS Trust Inquiry Report (Norwich: TSO, 2013) available at http://www.midstaffspublicinquiry.com/report.

${ }^{46}$ See, for example, Lord Sainsbury of Turville, Parliamentary Under-Secretary of State, Department of Trade and Industry introducing the Work and Families Bill to the House of Lords for its second reading: February $14^{\text {th }}$ 2006 Hansard Column 1090 - cited in G James above n20, p37. See also arguments for how children's welfare could be developed further in this regard in G James 'Forgotten Children: Work-Family Reconciliation in the EU’'(2013) 34(3) Journal of Social Welfare and Family Law 363.
} 
Hence, this final justification for action is based upon a related conviction that law is a vehicle for self-fulfilment during all stages of life ${ }^{47}$. Within our context, to reduce the lives of carers to those of 'would be' workers who could be contributing, or contributing more, to the economy as a whole and the profit margins of businesses and better preparing themselves for retirement, is to undervalue the contribution they make 'as carers' and underestimate the fact that the wellbeing of carer and dependant are often very closely intertwined ${ }^{48}$. It also fails to acknowledge how inaction, on the part of policy-makers or employers, can prevent workers with eldercare responsibilities from entering, participating and progressing in paid employment: how the barriers they create or reinforce by inaction make it very difficult for carers to benefit from financial security or to contribute to the economy through paid work, and hence denies them the chance to advance their own personal goals as 'workers'. Equally, to reduce the lives of recipients of care to 'burdens' is to undervalue the significant contributions older people have made, make, and the desire of many to continue to make with some support, to society as a whole. Indeed, many older people are carers themselves ${ }^{49}$, making a 'them and us' construction unhelpful in this context. Indeed, portraying the elderly as a potential 'burden on the young' is not only misleading, it perpetuates a culture of ageism that 'allows the younger generation to see older people as different from themselves' so that they 'subtly cease to identify with their elders as human beings, 50 .

At the heart of our argument in this paper is a call for recognition within employment law provisions of those who care for elder dependants and the recipients of care themselves - not simply because of their potential economic value but also because of their right to fulfil their

\footnotetext{
${ }^{47}$ See discussion in R O’Brooks “"The Refurbishing”: Reflections Upon Law and Justice Among the Stages of Life' (2006-7) 54 Buffalo Law Review 619.

${ }^{48}$ See Maduro's argument in Coleman v Attridge Law (Case C-303/06) [2008] IRLR 722: discussed in R Horton 'Care-giving and Reasonable Adjustment in the UK' in N Busby and G James above n 17, p137.

${ }^{49}$ See L Pickard et al 'Mapping the Future of Family Care: Receipt of Informal Care by Older People with Disabilities in England to 2032' (2012) 111 Social Policy and Society 533.

${ }^{50} \mathrm{R}$ Butler Why Survive? Being Old in America (New York: Harper and Row, 1975) p35.
} 
potential as human beings. Recognition theory is useful in the context of this argument: recognition is, according to Charles Taylor part of a 'vital human need' and is linked to a person's self-identity. As he put it,

'...our identity is partly shaped by recognition or its absence, often by the misrecognition of others, and so a person or group of people can suffer real damage, real distortion, if the people or society around them mirror back to them a confining or demeaning or contemptible picture of themselves, ${ }^{51}$.

As will be argued in Part 3 below, effective, focussed laws can help ensure that we do not 'mirror back' negative images of those who provide care or of the recipients of care themselves. As Sayer argues, recognition 'is not a luxury that ranks lower than the satisfaction of material needs, but is essential for well-being, ${ }^{, 52}$. Beyond financial incentives then, we ought to support the labour market participation of this cohort of working caregivers because, in a nutshell, to ignore the vulnerabilities and potential of these carers and the recipients of their care is to subtly support the 'benevolent prejudice' ${ }^{, 53}$ of ageism and to exploit caregivers which, given that the majority are women, reinforces gender inequality. As with any attempt to bring about social change, law is only ever a part, albeit an important part, of any 'solution' and employment law is an even smaller element of that equation. However, this is a prime example of labour law's 'special function' - to be 'the guardians of

\footnotetext{
${ }^{51}$ C Taylor 'The Politics of Recognition' in A Gutmann (ed) Multiculturalism and the Politics of Recognition, (Princeton, NJ: Princeton University Press, 1992) p25. For a useful discussion of Taylor's theory and interpretations of it see R Lister 'Recognition and Voice: the Challenge for Social Justice' in G Craig, T Burchardt and D Gordon (eds) Social Justice and Public Policy: Seeking Fairness in Diverse Societies (Bristol: Policy Press, 2008) 110.

${ }_{52}$ A Sayer The Moral Significance of Class (Cambridge: Cambridge University Press, 2005) p54.

${ }^{53}$ S Ray and E Sharp Ageism (London:Age Concern, 2006) p13.
} 
human beings in an age of almost unrestrained materialism, ${ }^{54}$. So whilst we ought not to over emphasise the power of law ${ }^{55}$ in this context, equally we ought not to underestimate employment law's potential to provide rights that can help shape the identity of carers and dependants in a more positive way through frameworks that provide these carers with a real choice, where feasible and preferred, to (re)enter or remain in paid employment.

\section{AN EFFECTIVE LEGAL RESPONSE?}

Lack of, or inadequate, legal engagement with eldercare-workplace conundrums, can reflect and reinforce ageist prejudices ${ }^{56}$ and gender inequalities and stump individuals' (carers and recipients of care) potential in life. Strong, supportive and purposefully applied laws can, on the other hand, "properly seek to intervene to prevent disadvantage flowing from that [prejudice] ${ }^{57}$ and inequality and hence, promote self-actualisation. If they are appropriately drafted and enforced laws can help remedy distortions in the labour market that lead to unjust and disproportionate disadvantages being experienced by those who provide care to elderly dependants. Governments across the globe have responded to this challenge in a variety of ways. Often, relevant laws are part of a broader package of rights for other care-giving activities, viewed as extensions of childcare provisions or sick leave entitlements. For example, the right to request flexible working was originally introduced in the UK in 2002 as a means of helping working parents to balance their work and care-giving responsibilities and hence modelled with this work-parenting conundrum in mind, and was only extended to

\footnotetext{
${ }^{54}$ The words of Hugo Sinzheimer as cited by B Hepple 'The Future of Labour Law' (1995) 21 Industrial Law Journal 303 at p322, and in B Hepple 'Employment Law under the Coalition Government' (2013) 42(3) Industrial Law Journal 203at p223.

${ }_{55}^{5}$ See C Smart Feminism and the Power of Law (London: Routledge, 1989).

${ }_{57}^{56}$ See J Herring above n 3, p3 and Chapter 2.

${ }^{57}$ Ibid, p9.
} 
those with caring responsibilities for adults under the Work and Families Act $2006^{58}$. The particular needs of those who care for elderly dependants seem to have been lost in this construction. As argued above, eldercare is less easy to define and lacks the typical projection of childcare, where the demise of care-giving need corresponds - on a similar trajectory for most children - with the recipient of care 'growing up' and attending school and becoming, over time, less dependent on the main carers. Eldercare, by contrast, is often 'messier' with blurred boundaries and divisions of care and no clear, average, progression that can be relied upon for the purpose of planning labour market participation. This relationship requires a different approach - one that is not modelled solely upon existing care-giving regimes and one that is sensitive to, and developed alongside, other legal/policy frameworks such as social security, immigration, healthcare and property laws. Herring's view that laws ought to recognise 'that our identities, values and well-being are tied up with our relationships and the responsibilities that come with them' is a good base upon which to start formulating such laws, not least because it challenges the normative assumptions of law that are often 'arranged around a vision of an able, autonomous and unattached adult' ${ }^{59}$. Only once we begin to tackle this issue in an holistic way can we begin to offer those facing this conundrum realistic, long term, alternatives to reducing hours, downgrading jobs or leaving the labour market altogether. In the remainder of this section we suggest what might improve legal engagement in this area. In essence, bearing in mind that this is only one piece of a much larger political puzzle, we suggest that 3 fundamental characteristics need to be present in order for employment legislation to better support working carers who wish to remain in the workplace and care for an elderly dependant: the legal provisions need to provide (a) financial support of some kind, (b) adequate coverage in terms of eligibility and scope and,

\footnotetext{
${ }^{58}$ See G James 'The Work and Families Act 2006: Legislation to improve choice and flexibility?' (2006) 35(3) Industrial Law Journal 272.

${ }^{59} \mathrm{Ibid}, \mathrm{p} 2$. In the labour market context - this 'autonomous and unattached adult' is often a male, 'unencumbered' worker - for an outline, see G James above n20, pp 17-18.
} 
crucially, (c) meaningful entitlement to short and long term flexible working - the type that can support the plurality of care needs that these carers are trying to negotiate and integrate into their working lives.

\section{a. Financial support}

Leave provisions need to be financially supported, in a way that minimises the direct burden often imposed upon individual carers. Whilst engagement with care-giving/workplace conundrums should never, as argued above, be reduced to a simple financial cost-benefit analysis, this aspect is one that still needs to be addressed. There are, of course, many views as to who should pay for care-giving ${ }^{60}$ and in practice, for those who combine work and care and do not wish to leave employment on a permanent basis, temporary absence from work is only usually viable when accompanied by payment of some kind. There are several ways that leave provisions can be financed but the sources of funds are usually, as Yang and Gimm comment, either by worker-carers themselves (hence, unpaid), employers or general revenue measures imposed on the population as a whole ${ }^{61}$. Employer and state funds are often viewed as inadequate sources because of the perception of care as a private matter. Others argue that asking employers to shoulder the financial burden can lead to cost-shifting behaviour, whereby the cost of the leave schemes are offset by reducing wages or not employing enough staff to undertake the work or, where relevant, transferring the cost to customers/service users. Relying upon national funds can be problematic too because of, it is argued, their sensitivity to changes in fiscal policy and the economic health of the nation, which is, in turn, likely to be sensitive to the world economy. To underscore this point, Yang and Gimm

\footnotetext{
${ }^{60}$ See e.g. Fineman's view of care as a 'social debt': M Fineman above n19, and Kittay's arguments that it ought to be paid for by taxpayers: EF Kittay 'A Feminist Public Ethic of Care Meets the New Communitarian Family Policy' (2001) 111 Ethics 523.

${ }^{61} \mathrm{~T}$ Yang and G Gimm 'Caring for Elder Parents: A Comparative Evaluation of Family Leave Laws' in (2013) 41 Journal of Law, Medicine and Ethics 501 at p507.
} 
highlight how Italy's National Fund for Social Policy was frozen following the European Financial Crisis and how this impacted upon the ability of regions to supplement the long term care of elders ${ }^{62}$. The fact that in the UK the pressures of the recession has been highlighted as a reason for deferring commitment to extend family-friendly leave entitlements, such as that of paid paternity leave and the extension of maternity and adoptive leave pay, is another example of the vulnerability of this type of social policy in the event of economic slowdown.

Our intention here is not to denote a 'correct' mechanism for financing leave provisions for workers with eldercare responsibilities, which often involves delicate balancing of resources at both state and employer levels. However, reluctance to source revenue from state funds or employers means that working carers themselves are often forced to carry the financial burden of care: a position that is ethically controversial and has, as argued above, long term repercussions for carers and state resource allocation. Sloan has suggested that private laws might be better utilised to compensate carers who could, in some situations, claim payment from the care-recipient (or his/her estate) ${ }^{63}$, but this goes against the grain of many academic critiques and is certainly contrary to the core premise of this article - that care-giving is itself of such benefit that it warrants state support ${ }^{64}$. However, as Sloan suggests, 'the recognition of care as something valuable and worthy of support... is crucial whether it is a public or private matter ${ }^{, 65}$ and this is ultimately what is lacking in many legal support systems.

\footnotetext{
${ }^{62}$ Ibid, p506.

${ }^{63}$ B Sloan Informal Carers and Private Law (Oxford: Hart Publishing, 2013).

${ }^{64}$ See also N Busby 'Unpaid Care-giving and Paid Work within a Rights Framework' in N Busby and G James above n 17, p190, who presents a convincing argument that 'more fundamental concerns of an ethical nature should underpin the prioritisation of competing claims for public resources'. See also N Busby A Right to Care? Unpaid Work in European Employment Law (Oxford University Press, Oxford, 2011).

${ }^{65}$ Above n 63, p7.
} 
Most countries are fairly weak in terms of payments offered when a worker needs to take leave to care for an elderly dependant. For example, the UK 'emergency' entitlement ${ }^{66}$ and the USA's Family and Medical Leave Act (FMLA) provisions are unpaid. Canadians, under the Compassionate Care Leave Programmes available for end of life care, receive some payment if they are members of the relevant insurance scheme - otherwise it too is unpaid. Eligible carers in New Zealand are entitled to paid sick leave that can be used in various scenarios, including when an elderly dependant is sick or injured, providing 5 days of sick leave a year. Australians also benefit from pay in relation to the 10 annual days personal/carers leave entitlement that is available to carers and the 2 days compassionate leave available to employees ${ }^{67}$ when a member of the immediate family or household develops an injury or illness that is life threatening. The former entitlement in Australia and the paid sick leave provisions in New Zealand need, however, to cover the carer's own sick leave and that of his/her children - as well as eldercare requirements. Clearly such a scheme favours the unencumbered worker who is, ironically, less likely to need to draw on the provisions. ${ }^{68}$.

Unpaid schemes are always going to be of limited value to working families with any caregiving responsibilities. Many carers use up their paid annual leave entitlements to cover short term care-giving needs, leaving them without a break all year, which can exacerbate poor health and stress levels ${ }^{69}$. Financial logistics help explain the limited uptake of the FMLA

\footnotetext{
${ }^{66}$ Employment Rights Act 1996 s.57.

${ }^{67}$ This is also available to casual workers although it is paid in the case of the former but not the latter. See $\mathrm{S}$ Charlesworth 'Law's response to the reconciliation of work and care: the Australian case' in N Busby and G James above n 17, p86.

${ }^{68}$ Which in Australia, can be accrued over the years and she/he can 'cash out' so long as the employer allows for this in writing and $\mathrm{s} /$ he retains at least 15 days of the untaken leave. The provisions, in this circumstance, financially reward workers who have not taken leave and, one might argue, penalises those who have had to undertake care-work and cannot benefit from this extra pay.

${ }^{69}$ See Carers UK The Case for Care Leave: Family, Work and the Ageing Population, (London: Carers UK, 2013) p8. See also, M Hirst Health Inequalities and Informal Care: End of Project Report (York: Social Policy research Unit University of York, 2004).
} 
provisions since its enactment over 10 years ago ${ }^{70}$ and demonstrate just how ineffective the USA provisions are. Only California, New Jersey and Washington have directly tackled the issue of non-payment, with insurance or wage replacement schemes. For example, California provides an employee with $55 \%$ of his or her wages for the first 6 weeks of leave up to a maximum of $\$ 882$ per week $^{71}$. This is clearly not the most generous provision when compared to Canada, but it is a vast improvement on the federal FMLA.

To offer leave that is unpaid or poorly paid severely restricts the choices open to those facing eldercare-workplace conundrums, drastically reducing their options when faced with a dependant in needs of their care. Some will need to provide that care outside of working hours, whilst others will be pushed to use annual leave entitlements. The lack of paid leave entitlement available during a time of flux, when decisions about long term care may need to be decided fairly rapidly will, for many, factor heavily in decisions to reduce hours or leave employment altogether. Long term financial ramifications of this are rarely factored into what are often short term responses by governments and employers. There are examples of schemes that provide much stronger financial support: the Netherlands, as part of a three tiered system of leave which includes emergency leave, short term leave and long term leave for workers with eldercare responsibilities, offers short term carer's leave of up to twice the hours worked per week, to a maximum of ten days per year and this is paid at a minimum of $70 \%$ of the employee's earnings ${ }^{72}$. Germany's approach offers another example worthy of note. Although requiring voluntary adoption by employers so not universally applied, it is revolutionary when compared with what is on offer in elsewhere: here, employers can offer 'Familienpflegezeit' (family caring time) which allows employees to reduce their working

\footnotetext{
${ }^{70}$ See J Waldfogel 'Family and Medical Leave: Evidence from the 2000 surveys' (2001) 124 (9) Monthly Labour Review 17.

${ }^{71}$ See T Yang and G Gimm above n 61, p504.

${ }^{72}$ L den Dulk 'Netherlands Country Note' in Moss, P (ed) (2013) International Review of Leave Policies and Research 2013 available at http://www.leavenetwork.org/lp_and_r_reports/review_2013/
} 
time to a minimum of 15 hours per week for a maximum of two years to care for a dependant relative. Paid at a reduced rate - but higher than the number of hours worked, the employee can repay the difference when s/he returns full time ${ }^{73}$. This provides a flexible mechanism that can be moulded to a particular set of circumstances and eliminates the financial stress that unpaid leave creates for the carer, whilst helping businesses retain workers.

\section{b. Adequate coverage}

Whilst payment is fundamental to enable those who need to do so to take leave, its usefulness is undermined if the worker is not able to access the right in the first place, or not able to do so in relation to his/her particular eldercare emergency or incident. The provisions, in order to provide an adequate legal response to the eldercare-workplace conundrums, need to be accessible by all workers with eldercare responsibilities and for all types of care - including, sudden, emergency situations, end of life care and the mass of potential care-giving situations that can occur to workers who undertake this journey. Unfortunately many leave provisions are either restrictive in terms of eligibility or in terms of scope.

In the USA, New Zealand and Australia leave entitlements, and where relevant rights to request flexible working, are restricted to those who have been employed for a specific duration of time. Requirements vary from 6 months (New Zealand) to 12 months (USA and Australia) employment and the FMLA also specifies that a minimum number of hours need to have been worked for that employer during that period. By limiting coverage in this way, governments immediately restrict the ability of many worker-carers to provide care for a dependant, should the need arise, without compromising workplace relations. Females, who make up the majority of part-time workers and those employed on precarious short-term,

\footnotetext{
${ }^{73}$ S Blum and D Erler 'Germany Country Note' in Moss, P (ed) (2013) International Review of Leave Policies and Research 2013 available at http://www.leavenetwork.org/lp_and_r_reports/review_2013/
} 
casual contracts, are particularly disadvantaged which has a specific impact on gender equality goals. In Australia the provisions are particularly detrimental to casuals, as almost half are in jobs for less than a year ${ }^{74}$. In addition, most provisions only cover employee care for particular cohorts of people and these definitions vary from country to country. For example, the UK emergency leave provision is fairly wide, covering parents, grandparents or those dependant on him/her for care. Canada's compassionate care leave is available to care for a 'family member', whilst New Zealand's right to leave includes care for 'a spouse, child or other dependant', and the FMLA is only available to care for biological or adoptive parents, and is thus of no use to grandchildren or close friends who are able/wanting to undertake a care-giving role.

Legal provisions are also often limited because they are only applicable in certain care-giving situations. The UK emergency leave provisions are no more than a right to arrange alternative care $^{75}$ which is of no use to those who need to provide care themselves. Restrictions in scope are also evident in New Zealand's provisions. Here, the entitlement to claim sick leave provides a care-giver with some limited capacity to be away from work in the event of a dependant experiencing a sudden illness or injury, but it cannot support situations where the recipient of care needs more regular care-giving over a longer period. The compassionate care leave programme in Canada and the 2 days compassionate care leave provisions in Australia are also defined and operate in a way that limits its potential usefulness to workers who need to be absent for reasons other than to be with relatives who are gravely ill or at significant risk of death. Such provisions are not going to aid those workers needing to respond to other events where their presence and care is needed. Interestingly, a similar 'end of life' scheme is available in Belgium - where palliative care leave of one month, with the

\footnotetext{
${ }^{74} \mathrm{~S}$ Charlesworth 'Law's response to the reconciliation of work and care: the Australian case' in N Busby and G James above n 17, p96.

${ }^{75}$ Qua v John Ford Morrison Solicitors [2003] ICR 482 EAT.
} 
possibility of extending for another month is available to employees and paid at the same rate as parental leave. In Belgium though, this palliative care leave is part of a broader package of rights that includes emergency unpaid leave of 10 days and up to 12 months care leave for a seriously ill family or household member - to be taken in blocks of one to three months, although the latter is only available to private sector workers ${ }^{76}$.

Other methods of limiting the scope of the relevant leave entitlements have also been deployed. The FMLA only covers employers with 50 or more employees, hence the majority of employees (60\%) are simply not eligible to claim FMLA leave, either because they themselves do not have the requisite history of employment or because their employer is not covered $^{77}$. Hawaii, Maine and Oregon have attempted to tackle this - expanding their definitions so as to increase coverage either by reducing the number of employees required so as to increase the number of smaller employers covered by the Act (Maine), or reducing the eligibility criteria for employees (Hawaii), or both (Oregon) ${ }^{78}$. These, and other variations, such as extending leave time and reducing the 'hours worked' eligibility criteria, have improved the FLMA in some states but, on the whole the eligibility and coverage limitations mean that the provisions in the USA are disappointing, providing very little support to carers of elderly dependants who participate, or would like to participate in paid employment. Furthermore, in the USA, the FMLA is the main family leave provision, covering childcare leave entitlement as well as elder dependent care, thus its use to dual-carers is immediately diluted as the 12 week entitlement might need to be spread more thinly between the recipients of care in that family. Similarly, carers in New Zealand will need to sacrifice a leave

\footnotetext{
${ }^{76}$ L Merla and F Devan 'Belgium Country Note' in Moss, P (ed) (2013) International Review of Leave Policies and Research 2013 available at http://www.leavenetwork.org/lp_and_r_reports/review_2013/

${ }^{77}$ FMLA Surveys available at http://www.dol.gov/whd/fmla/survey/ cited in T Yang and G Gimm above n 61, p503.

${ }^{78}$ See T Yang and G Gimm above n 61, p504.
} 
entitlement that might have been used to enable leave in the event of their own illness or injury or, for sandwich carers, that of a child.

Most of the provisions considered here limit coverage in one way or another - some are limited to such a degree that their ability to provide an adequate response to the eldercareworkplace conundrums discussed above is severely undermined. Leave entitlements are important to support workers who are endeavouring to care for elderly dependants in the short to medium term, but need to be available to all carers, regardless of employment history, size of employer or hours worked. Equally, leave needs to be of a reasonable duration and enable workers to respond to issues that cannot be dealt with in a matter of hours or days but will not necessarily result in long term dependency that might require a permanent alteration to workplace engagement.

\section{c. Flexible working}

Employment law frameworks need to be open to flexible working-and in a way that reflects the plurality of eldercare/workplace experiences. The notion that there is a particular profile to which all, or even the majority, of care-givers conform is unhelpful in this context. Equally, the diversity of paid employment needs to be factored into discussions about the potential for flexibility. Hence systems that allow for a variety of care-giving/working realities and are able to help carers manage fluctuations in care-giving needs and workplace responsibilities are crucial within this context. The availability of flexible working arrangements is key as it provides malleable options that can cater for the plurality of circumstances that shape the eldercare/workplace conundrum. It is disheartening that very few countries actually provide workers with opportunities to work flexibly. Of the 34 countries considered in the latest review of leave policies by the International Network on 
Leave Policies and Research ${ }^{79}$ - only 5 countries offer any right to request flexible working (Australia, Ireland, Italy, New Zealand and the UK) and in two of these countries (Italy and Ireland) entitlement is limited to parents. This demonstrates that, globally, the options available to many working carers with elderly dependants are severely restricted. Interestingly only one country, Portugal, actually entitles workers to flexible working, allowing those who are eligible to choose when to start and finish daily work. However, it is applied with certain limits, the most relevant to us being that it is limited to parents with children under 12 years old ${ }^{80}$.

Within the global context, regimes on offer in the UK, Australia and New Zealand that allow workers the right, in certain situations, to request changes to hours, time or location of work or a mixture of these, must be commended. However, the ability of these schemes to promote substantive change is also limited because the rights have been drafted in a way that makes them, in terms of nature and scope, very rigid. Flaws in terms of eligibility have, where relevant, been highlighted above but in order for the potential of these schemes to be met they also, arguably, need as a minimum to embrace the following two characteristics. First, the right to request flexibility needs to be better supported by mechanisms that encourage employers to seriously engage with the worker in order to reach a mutually acceptable plan that enables the care-giving and the work roles to be carried out. The schemes allow the employer to refuse the request for very broad business-related reasons. In Australia for example, Employers can refuse the request on 'reasonable business grounds', which includes cost, capacity to change the working arrangements of other employees in order to accommodate the request or because it would be 'impractical' to do so or have significant negative impact on customer service. Legislation empowers the Fair Work Commission (or

\footnotetext{
${ }^{79}$ P Moss (ed) International Review of Leave Policies and Research 2013 (2013) available at http://www.leavenetwork.org/lp_and_r_reports/review_2013/

${ }^{80}$ Longer if the child is chronically ill or disabled: Ibid, p244
} 
another person) to deal with a worker's appeal against a refusal - so long as this is contained within his/her employment contract or other written agreement. Similarly in New Zealand, denials are permitted where to allow flexibility would damage business operations, have a detrimental impact on work quality or performance or because of an inability to recruit additional staff. The legislation here provides a grievance process where the employee feels that the employer has not dealt with the request correctly, and the employer can ultimately be fined \$2000 if the Employment Relations Authority find in the employees favour. In all countries the substance of the decision is not open to appeal/review, and in all cases, once refused, the employee is not at liberty to make another request (or modify/negotiate the existing one) for 12 months. This reduces individual autonomy to react to care needs when required and reduces the ability of workers, as a cohort in the labour market, from really challenging the boundaries of workplace cultures.

Second, in order to realise its potential schemes need to provide realistic opportunities for workers to accommodate fluctuations in need - both in their roles as care-givers and workers. The UK and Australia allow only for permanent changes to be made to the employment contracts and none of the schemes considered here, provide opportunities for re-assessment over time. A better approach would be one that enables workers to modify arrangements on a temporary basis, as in New Zealand, and provides, where needed, mechanisms for regular ongoing monitoring of agreements, with opportunities for both parties to discuss and where relevant revise, the adjustments that have been made. It is also useful to reflect upon the nature of flexible working in a more holistic manner so that discussion can be had not only about the choice of hours and location of work but also about the pace of work, otherwise the burden of implementing flexible work arrangements and managing huge, time pressured, 
workloads is borne by the individual and counteracts the very flexibility that has been negotiated and agreed ${ }^{81}$.

Whilst existing rights to request flexibility could be improved along these lines, other approaches offer alternatives worthy of consideration. The tiered approaches in Belgium and the Netherlands provide a useful approach, offering some opportunities for working carers to try and manage the care need without having to leave employment or reduce hours on a permanent basis. The German provision, discussed above, also has the potential to empower carers - providing a realistic means of managing their time in a way that preserves their identity as workers and carers and opens up space for negotiations as to how the change might be implemented in practice. Interestingly, in the Australian province of Victoria antidiscrimination law provisions have been used in an imaginative way to protect parents and carers, and facilitate their participation in the labour market. Laws prohibit unreasonable refusal to accommodate an employee's care-giving responsibilities ${ }^{82}$, and this is widely viewed as a 'ground breaking, ${ }^{83}$ provision. By prohibiting unreasonable refusal to accommodate an employee's ${ }^{84}$ care-giving responsibilities this provides the possibility for a substantive review of employers' refusal to accommodate where it applies to parents and carers. It places responsibility squarely on the employer to demonstrate that they have not unreasonably refused to accommodate the worker's carer status, effectively introducing what

\footnotetext{
${ }^{81}$ See N Donnelly, S Procter-Thomson and G Plimmer "The role of "voice" in matters of "choice": Flexible work outcomes for women in the New Zealand public services' (2012) 54(2) The Journal of Industrial Relations 182.

82 See S Charlesworth and I Campbell 'Right to Request Regulation: Two New Australian Models' (2008) 21(2) Australian Journal of Labour Law 1.

${ }^{83} \mathrm{~S}$ Charlesworth 'Law's response to the reconciliation of work and care: the Australian case' in N Busby and G James above n17, p98.

${ }^{84}$ Legal action may be brought by a casual worker who feels that his/her carer responsibilities have not been accommodated but it seems, following cases on the issue, that a lower expectation exists in relation to what is expected of an employer where casual workers are concerned - E.g. Richold v Department of Justice (Corrections Victoria) [2010] VCAT 433 discussed in S Charlesworth 'Law's response to the reconciliation of work and care: the Australian case' in N Busby and G James above n 17, p99.
} 
has been termed 'a third form of discrimination, ${ }^{85}$ in this context - to unreasonably refuse to accommodate a carer (or parent's) responsibilities. Horton has convincingly suggested that the duty to provide reasonable adjustments in UK anti-discrimination law might be extended in a similar way, to workers who provide care: an appealing option if only because it doesn't suffer from the shortcomings of right to request schemes. Other schemes might also be applied - for example, a right to work part time for a limited period. The latest International Review of Leave Policies shows that in 14 of the 34 countries considered parents had a legal right to work part time, although length, payment and other dimensions varied between countries. For example, in Japan, although there is no right to request flexible working, parents with children under the age of 3 have a right to work a reduced day (of 6 hours) ${ }^{86}$. These offer interesting alternatives to flexible working that might usefully be explored in relation to workers with eldercare responsibilities. There is clearly no singular, perfect template that can usefully be applied to all countries, but the existence of imaginative legal responses to work-life balance conundrums in general is heartening, providing ample food for thought in terms of how we might improve labour law's engagement in this area.

\section{CONCLUSION}

As a result of changes in social norms and the intensification of working life, care of older people is no longer woven into everyday life but increasingly professionalised and has become, for many, an additional pressure point: something "to be managed". We have

\footnotetext{
${ }^{85}$ I.e. beyond direct and indirect discrimination: A Chapman, A 'Care Responsibilities and Discrimination in Victoria: The Equal Opportunity Amendment (Family Responsibilities) Act 2008 (Vic)' (2008) 21(2) Australian Journal of Labour Law 200 at p207. For a discussion of how the duty to provide reasonable adjustments should be extended in the UK to those who care see R Horton 'Care-giving and reasonable adjustment in the UK' in N Busby and G James above n 17, p137.

${ }^{86}$ Above $\mathrm{n} 79$.
} 
witnessed a 'decasualisation' of the care of older people ${ }^{87}$ and, perhaps because of the relationship between decasualisation and increased female employment, the elder-care 'problem' and its 'solution' has often been constructed as an extension of work-life balance debates. However it is framed, governments across the world clearly need to find ways of better researching, articulating, defining and reconciling this new and growing tension between paid work and unpaid care - a conundrum that it is no longer, if it ever was, wise to pursue as an awkward extension of childcare/paid work contexts. Eldercare, and the plurality of experiences it embodies, needs to be factored into a wide range of social and economic policies as a matter of urgency ${ }^{88}$ - and one aspect of this long overdue shift in perspective has to involve consideration of the employment rights available to carers of elderly dependants who participate in paid work. Adequate laws are important here not only in order to ease the day to day existence of these individual working carers by helping them 'meet the unyielding demands of the care relationship within what are often inflexible workplace arrangements ${ }^{, 89}$, but also to help ensure that the needs of the recipients of care can be met. Only then can we create opportunities for these crucially important caring relationships to flourish alongside labour market participation.

\footnotetext{
${ }^{87}$ R Goodwin and D Gibson 'The Decasualisation of Elder Care' in EF Kittay and E Feder (eds) The Subject of Care: feminist perspectives on dependency (Totowa, NJ: Rowan and Littlefield, 2003).

${ }^{88}$ As Horton point out, effective working arrangements and legal rights for working carers are of limited use if they are not supported by the care system - e.g. by adequate day care provisions - see R Horton 'Care-giving and Reasonable Adjustment in the UK' in N Busby and G James above n17, p139.

${ }^{89} \mathrm{~N}$ Busby 'Unpaid Care-giving and Paid Work within a Rights Framework' in N Busby and G James above n17, p203. See also N Busby A Right to Care? Unpaid Work in European Employment Law (Oxford University Press, Oxford, 2011).
} 